\title{
Article \\ Effects of Coating Materials as a Cleaning Agent on the Performance of Poly-Crystal PV Panels
}

\author{
Khaleel Abushgair 1,*(D) and Rafat Al-Waked ${ }^{2}$ (D) \\ 1 Mechanical Engineering Department, Faculty of Engineering Technology, Al-Balqa Applied University, \\ Marka, Amman 11134, Jordan \\ 2 Department of Mechanical and Maintenance Engineering, German Jordanian University, \\ Amman 11180, Jordan; Rafat.Alwaked@gju.edu.jo \\ * Correspondence: abushgair@bau.edu.jo
}

check for updates

Citation: Abushgair, K.; Al-Waked, R. Effects of Coating Materials as a Cleaning Agent on the Performance of Poly-Crystal PV Panels. Coatings 2021, 11, 544. https://doi.org/ 10.3390/coatings11050544

Academic Editor: Meen Teen-Hang

Received: 25 March 2021

Accepted: 3 May 2021

Published: 5 May 2021

Publisher's Note: MDPI stays neutral with regard to jurisdictional claims in published maps and institutional affiliations.

Copyright: (C) 2021 by the authors. Licensee MDPI, Basel, Switzerland. This article is an open access article distributed under the terms and conditions of the Creative Commons Attribution (CC BY) license (https:// creativecommons.org/licenses/by/ $4.0 /)$.

\begin{abstract}
Hot and arid areas are considered a harsh environment when it comes to cleaning photovoltaic (PV) modules. Minimizing the panel tilt angle makes it evident that dust and other substances such as airborne dirt (both organic and inorganic) and bird droppings can build up over time and impact the amount of electricity generated by a module. The current study aims to find the most effective and optimum cleaning technique/material based on cleaning performance of the PV panel. The effects of different easy-to-clean materials on the performance of poly crystalline silicon type PV modules were experimentally investigated. As there is no specific recommended material to clean solar panels, the cell surface was coated with different types of easy-to-clean materials available in the Jordanian local market. The cleaning materials utilized were: Crystal glass coating type AJJL-CSS, jiajialy nano energy saving \& anti UV solution, GIE (Galsilk 7, isopropanol, ethanol, water), TGIE $\left(\mathrm{TiO}_{2}\right.$, Galsilk 7, isopropanol, ethanol, water), sodium hexa meta phosphate, and NanoUltra. Results from temperature measurements and output voltage of coated cells showed that all coating materials were able to reduce the cell temperature in different scales. The jiajialy nano energy saving \& anti UV solution provided the best cooling effect, while the GIE and TGIE showed good results, too. Output voltage of cells coated with GIE and TGIE materials was the highest.
\end{abstract}

Keywords: easy to clean materials; PV panels; PV performance; dust

\section{Introduction}

In today's climate of increasing demand for electric power consumption and the huge concern for environmental safety from power plants, it is necessary to find new renewable energy sources to replace the fossil fuel driven power stations. Therefore, the acceleration in research in renewable energy sources protrudes to meet the high demand for energy with the least possible pollution [1,2].

Solar energy is considered to be the richest renewable energy source among others. Solar cells convert solar radiation into electrical energy. Unfortunately, an amount of energy is lost during this process and the amount of energy lost due to high temperature of photovoltaic cells is very large, which reduces the cell efficiency and lifespan. Therefore, decreasing photovoltaic cells temperature and reducing the accumulation of dust can raise the electrical efficiency. Air cooling and water cooling were used to reduce the cell temperature. However, this technique may require additional costs for hardware installation and maintenance $[3,4]$.

The Middle East could be considered a worst-case scenario for solar panels due to air high dust intensity and the frequent occurrence of sandstorms. This could plaster a solar panel with a thick layer of dust and residue in less than $1 \mathrm{~h}$. Consequently, efficiency of solar panels could be reduced by up to $80 \%$. Therefore, panels should be cleaned regularly or almost daily, to prevent them from becoming practically useless. The reduced efficiency resulted from dust accumulation might not be a challenge restricted to arid and desert 
zones only [1-4]. One method to accomplish temperature and dust reduction without the need to install any additional hardware is to apply coating cover glass of solar cells. The cover consists of a specific material to absorb high energy photons from the ultra-violet rays and to re-emit them in the visible range spectrum with lower energy. This would ensure reduction in the amount of heat generated by photons and ensure reduction in dust accumulation [5].

Performance and power output of a photovoltaic (PV) module is directly affected by environmental conditions where the module is placed and dirt accumulation of dust and airborne dirt (both organic and inorganic) on the front cover (mostly glass or a polymer). Dust accumulation on solar cell glass panels depends mainly on the tilt angle of PV panels and orientation, surface roughness, and type of cleaning coating. Furthermore, it depends on external ambient parameters like humidity, temperature, and wind speed. Regional characteristics like traffic, air pollution, and plants play a crucial role in dust deposition, too. Other properties of dust influence the accumulation of dust on the surface of panels such as: shape, size, and weight of the dust particles $[1,4,6,7]$. The accumulated dust thickness is a function of time and varies with diverse site-specific weather and environmental, texture of the front glass, tilt angle of the PV modules, and type of soiling agent.

Research groups studied the impact of shading due to dust accumulation and/or dirt. Sarver et al. [6] reviewed impacts of dust on the use of solar energy and Maghami et al. [7] wrote an updated evaluation on the same topic. They reported that shading has a prominent negative effect on the power output from a PV module. Researchers in the Middle East investigated the effect of dust accumulation on solar cell glass panels. Results showed that a $32 \%$ reduction in performance of the solar panels could occur due to dust accumulation, which enhances the reduction in plate-transmittance.

The literature review has shown that there are no commercially available cleaning materials that have been approved as easy-to-clean materials for solar panels. In order to achieve such a material that exists at low cost and high cleaning efficiency, a need for developing customized materials exists. The development of customized materials starts from available easy-to-clean materials for glass to overcome drop of efficiency of solar panels due to heat and dust accumulation.

Jordan depends on solar energy in producing $20 \%$ of its electrical energy needs. The objective from the current study is to improve the electrical efficiency of the photovoltaic cells. Therefore, the performance of poly crystalline silicon panels under different coating materials has been investigated experimentally. The cell surface has been coated with different types of easy-to-clean materials founded in the Jordanian local market and used as easy-to-clean materials for glass surfaces. The main cleaning materials and techniques that are compared in this study as hydrophilic and super hydrophilic coating materials are: Crystal glass coating type AJJL-CSS jiajialy nano energy saving and anti UV solution, GIE and sodium hexa meta phosphate, as well as Nano Ultra as superhydrophobic coating material. Furthermore, a new material (TGIE) was developed in-house based on mixing GIE material with $\mathrm{TiO}_{2}$ nanoparticles to improve the dirt cleaning effect. Many cleaning techniques are used simultaneously to increase cleaning effectiveness by reducing dust accumulation, reversing ultraviolet radiation, and reducing cell temperature. Results were reported in terms of cell temperature and voltage output.

\section{Materials and Methods}

\subsection{Chemical Self-Cleaning}

Self-cleaning Nano films can be in the form of super-hydrophilic, super-hydrophilicity, and Superhydrophobic coating films [8]. Yilbas [9] summarized self-cleaning Nano films and emphasized the importance of self-cleaning surfaces as a solution for cleaning of the solid surfaces. Syafiq et al. [10] studied the development in different self-cleaning methods for PV panels. They mainly focused on super-hydrophilic and superhydrophobic coatingbased materials as self-cleaning. The superhydrophobicity and self-cleaning property of lotus leaf absolutely induced by the synergy of rough micro and nano surface structures 
consist of a hierarchical array of nano-wax clusters, nano-wax tubules, and micro-papillae, as the lotus leaf surfaces structure. A super-hydrophilic coating with high transparency and ultrahigh adhesive force was designed and prepared by Liang et al. [11]. The coating was developed for use on the glass covers of solar cells, which exhibited excellent thermal stability and strong acid-base corrosion resistance.

The popular type of coating film contains $\mathrm{TiO}_{2}$ nanoparticles [12,13], which clean the solar panels through the following steps:

- Photocatalytic process would take place where the coated film reacts under the ultraviolet light. This splits the organic dirt and rainwater removes dust.

- The coating material increases the contact angle (CA) to a value larger than 150 degrees, which allows falling water droplets on the surface to quickly spill off and carry dust and other particles away.

The developed material requires a large amount of water, which makes it not well suited for desert climates [14]. Piliougine et al. [15] studied different easy-to-clean coating films and reported $2.5 \%$ of an average daily energy soiling loss and $3.3 \%$ loss for uncoated modules. Coating transmission losses have been experimentally investigated to reduce the path length. Moreover, the quantity of incident light reaching the solar cell module could be increased by incorporating anti-reflection and light-scattering patterns [16]. Pedersen et al. [17] showed that over the 2-month period of the test, a loss in efficiency was in the range of $0.2-0.3 \%$. This number was estimated based on $1-2 \%$ transmission losses. Oh et al. $[13,18]$ utilized silica-based antireflection and anti-soiling coatings for which about $2.56 \%$ increase was achieved on average because of the anti-reflection coating. Dash, Prabir [19] experimentally evaluated the temperature coefficient of different types of solar panels. It is found that the average temperature coefficient of power for mono-crystalline is $-0.446 \%$ per degree Celsius, poly crystalline $-0.387 \%$ per degree Celsius, and $-0.172 \%$ per degree Celsius for CdTe. In the case of the amorphous silicon module, it was $-0.234 \%$ per degree Celsius. The study showed that the temperature coefficient for mono crystalline silicon module is higher than other types

\subsection{Experimental Procedure}

Both coated and bare solar panels were installed side by side and experiments were conducted on both panels simultaneously. Each panel is connected to two LM35 sensors to measure and compare the average temperature with and without an easy-to-clean coating layer. One saLM35 sensor connected separately to measure the ambient temperature, as shown below in Figure 1. Arduino IDE software is used to collect data of PVs temperatures from all sensors and voltage of coated and bare solar panels [20,21].

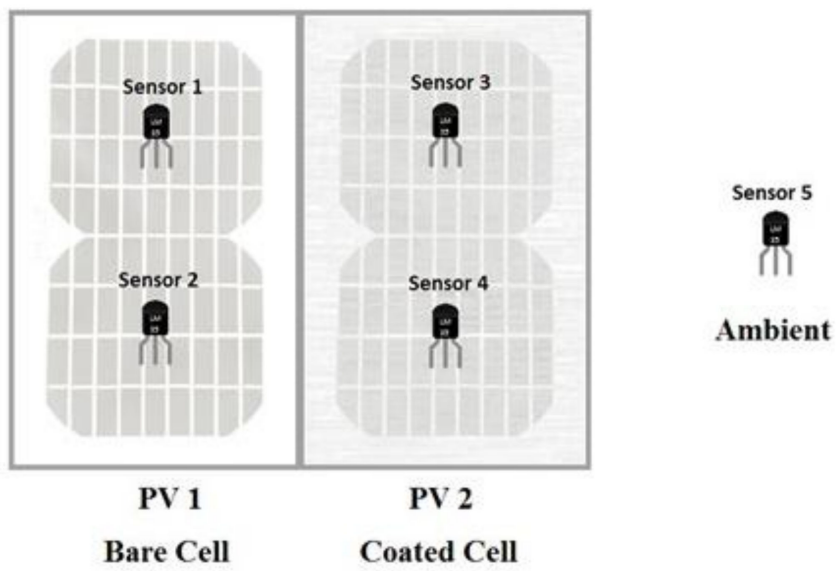

Figure 1. LM35 sensors location on solar panels. 
Each panel was prepared in accordance with the following steps to be ready for collecting data:

- Cleaning the panel glass surface by soup

- Drying the glass using clear cotton fabric

- Wiping the glass with alcohol to remove any dirt

- Distributing the cleaning agent on the glass

- Wiping the material to produce a thin layer by considering the direction of wiping (counterclockwise)

- Leaving the cleaning agent on the panel for enough time to dry.

\section{Results and Discussions}

In this section, effects of different easy-to-clean materials on the cell temperature and output voltage are reported.

\subsection{Both Cells without Coating}

Figure 2 shows the ambient temperature of both solar cells in Amman-Jordan for the period from 7:00 a.m. to 5:00 p.m. and the inside temperature of the solar cell. Both cells showed similar trends in temperature with ambient temperature being lower than cell temperatures by approximately 1 degree Celsius at midday. It has been noticed that at early morning and later afternoon the ambient temperature was higher than the cell temperature. This could be due to the absence of direct sun rays on the cell and nature of cell frame being manufactured from metals with high conducting rates. Furthermore, the difference in readings from the two cells could have resulted from cell manufacturing and/or error in reading.

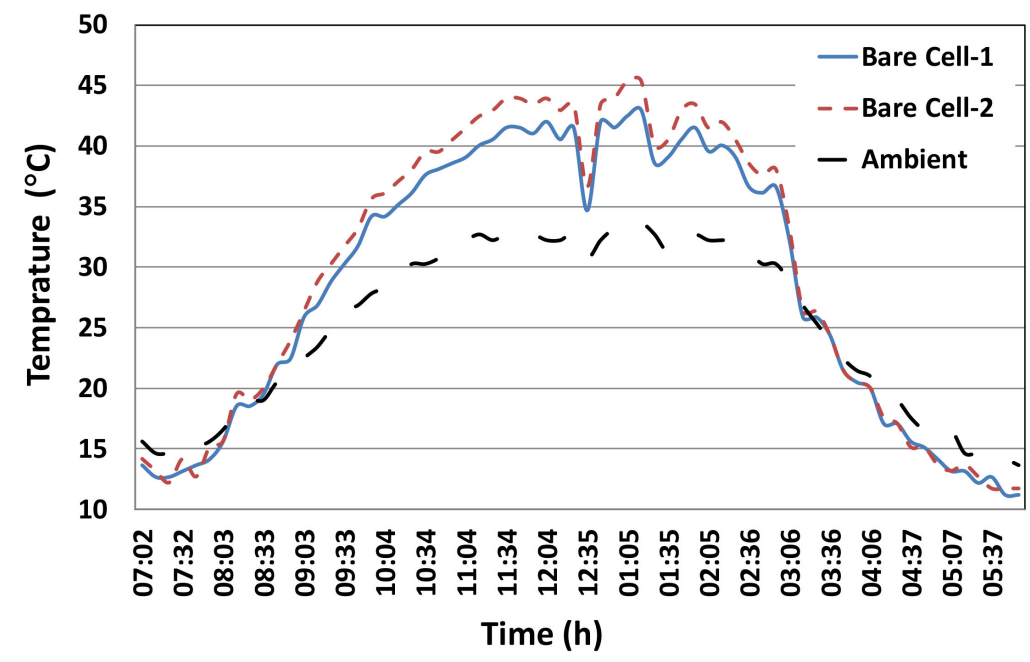

Figure 2. Temperature difference of PVs without coating, Amman-Jordan.

Figure 3 shows the Voltage difference of both cells without coating according to Amman-Jordan ambient conditions. The presented measurements showed that the cell with higher temperature had lower voltage reading and vice versa. It is worth mentioning that voltage curves showed similar trends to temperature curves at a given time during a given day. Moreover, it is clear that cell 1 showed lower output voltage than cell 2 with a difference of around 2 volts. This difference will be considered during other test measurements. 


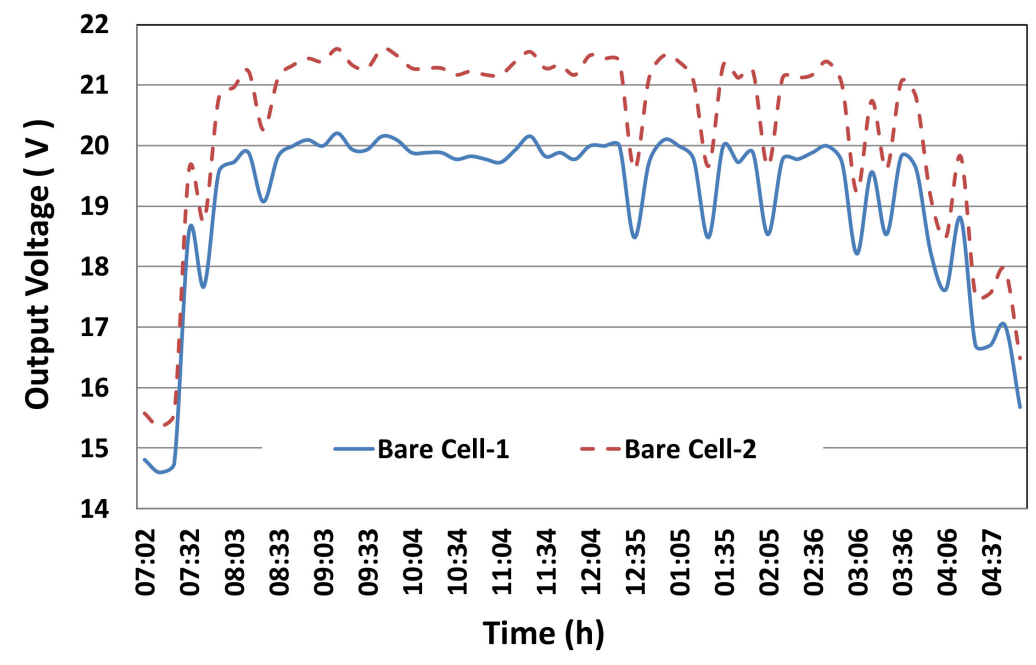

Figure 3. Temperature difference of PVs without coating, Amman-Jordan.

\subsection{Crystal Glass Coating Type AJJL-CSS}

Crystal glass coating type AJJL-CSS is a liquid component aqueous acidic alcoholic solution with special active agents $(\mathrm{PH}=6)$ super hydrophilic, anti-dust and mud with good transparency, and non-toxic material. The weather measurement day was cloudy and dusty.

Figure 4 shows the temperature variation for coated and bare cells. The temperature difference between the bare cell and the coated cell early morning at 9:00 a.m. was about $2.5^{\circ} \mathrm{C}$. The difference increased to a maximum value of $10{ }^{\circ} \mathrm{C}$ at midday at $12: 30 \mathrm{p} . \mathrm{m}$, which means that the AJJL-CSS material acts better at high temperature. Figure 4 shows that adding AJJL-CSS to the cell glass surface resulted in reducing the cell temperature due to a lower amount of ultraviolet (UV) sun rays penetrating through the coated glass. Consequently, there has been a noticed light improvement of the output voltage for the coated surface over the uncoated surface as shown by Figure 5. It should be kept in mind the difference in measurement between the two cells as noted in Figure 2.

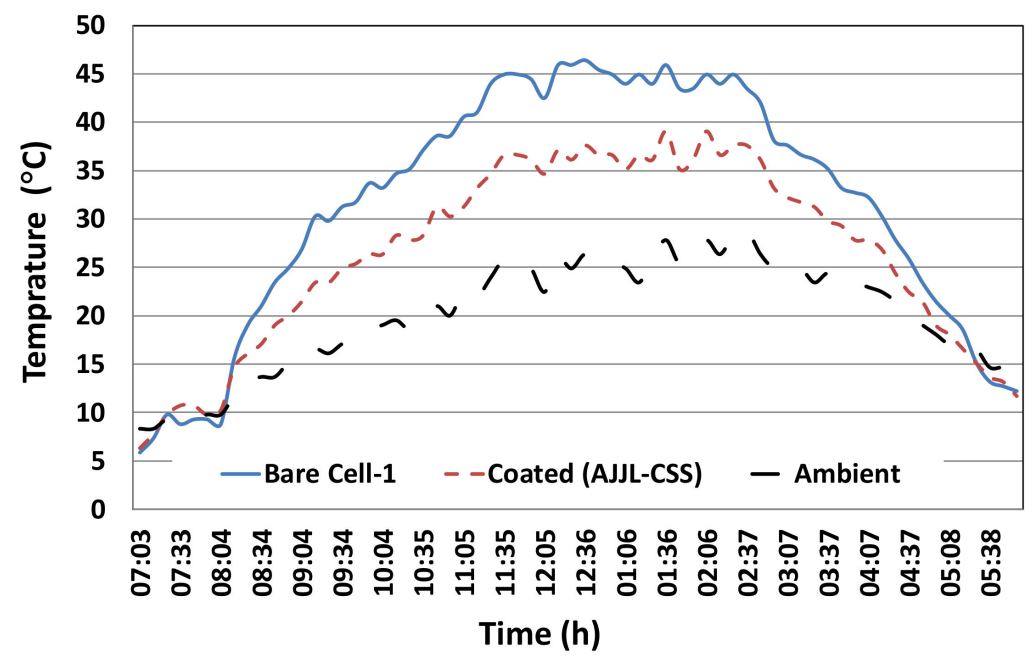

Figure 4. Temperature difference of PVs with and without Crystal Glass Coating Type AJJL-CSS, Amman-Jordan. 


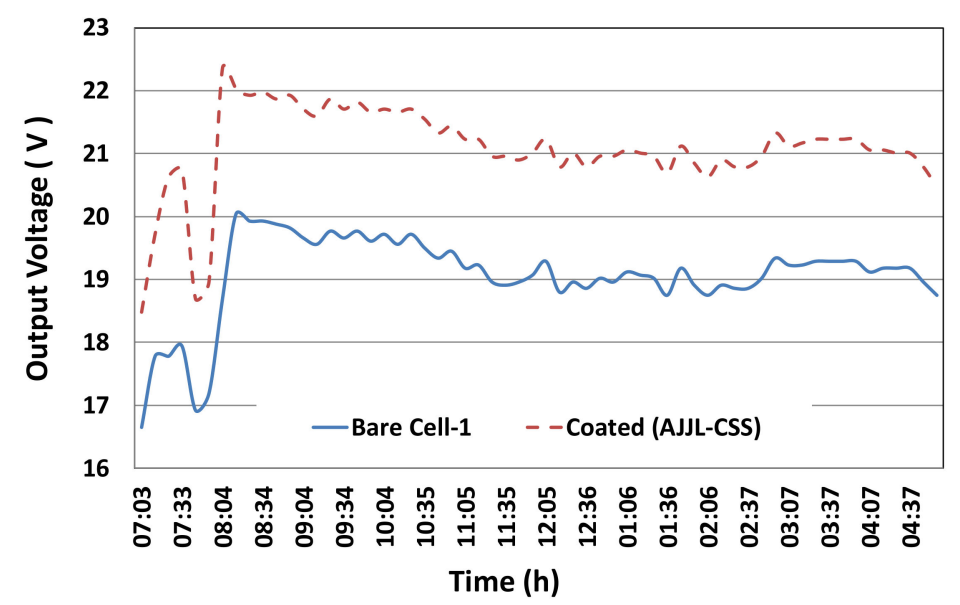

Figure 5. Voltage difference of PVs with and without Crystal Glass Coating Type AJJL-CSS, Amman-Jordan.

\subsection{Jiajialy Nano Energy Saving and Anti UV Solution}

It is a nano high-tech transparent glass coating material for energy saving within buildings by heat insulation with characteristics of high rejection of infrared (IR) and UV. Its fundamental raw material is nano metal oxide particles and resin. It is manufactured through the chemical composition process. It quickly forms into a transparent heat insulation layer with thickness of 8-10 $\mu \mathrm{m}$ after painting on glass surface as shown by Figure 6. It is the best super hydrophilic transparent heat insulation coating for energy saving upgrading or standard realization of normal glass. It can be widely used in building glasses, vehicle and ship glasses, synthetic glasses for heat insulation, and energy saving glass. The weather measurement day was hot and dusty. It is worth mentioning that the added coated material attracted more dust to the surface, which is hard to remove by air blowing mechanism.

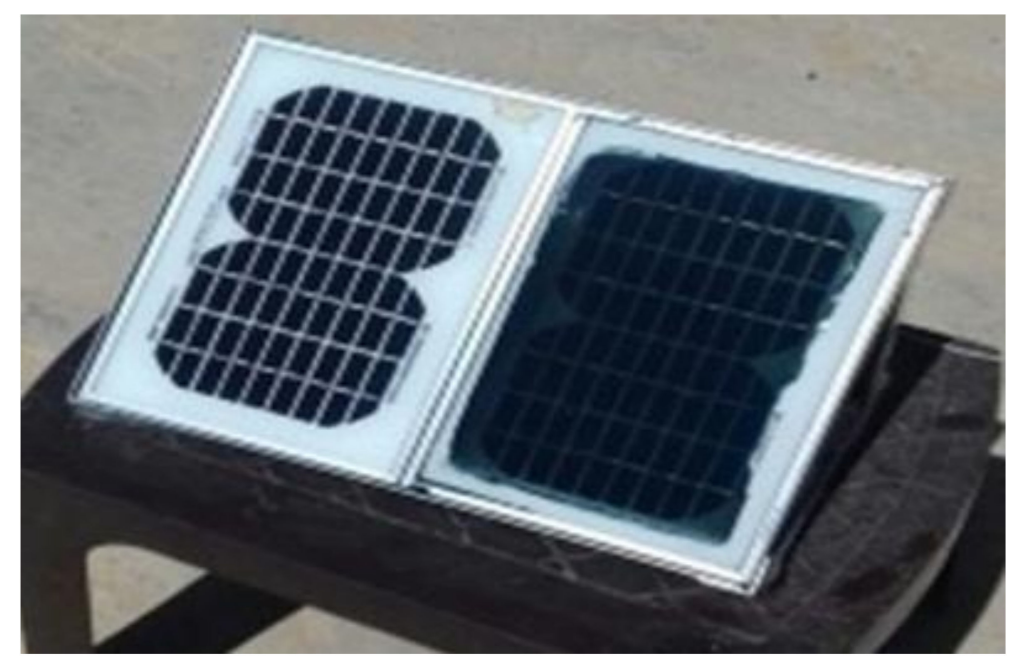

Figure 6. Jiajialy nano energy saving and anti-UV solution.

Figure 7 shows that Jiajialy coating material was applied to decrease the cell temperature due to a lower amount of ultraviolet sun rays (UV) penetrating through the coated glass. Consequently, there has been a noticed decrease in the output voltage for the coated surface over the uncoated surface as shown by Figure 8, keeping in mind the difference in measurement between the two cells as noted in Figure 2. This could be due to the fact that Jiajialy layer decreases the transparency of cell glass and reduces the amount of visible light reaching the silicon layer, which is responsible for producing the energy. 


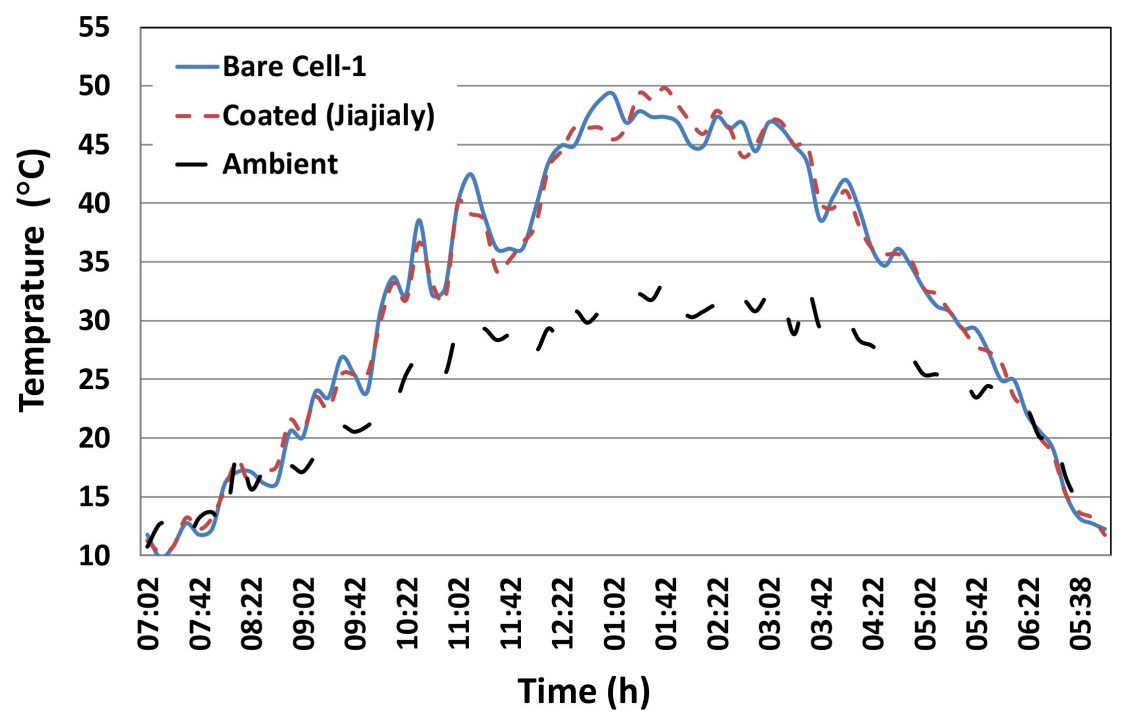

Figure 7. Temperature difference of PVs with and without Jiajialy nano energy saving and anti-UV solution, Amman-Jordan.

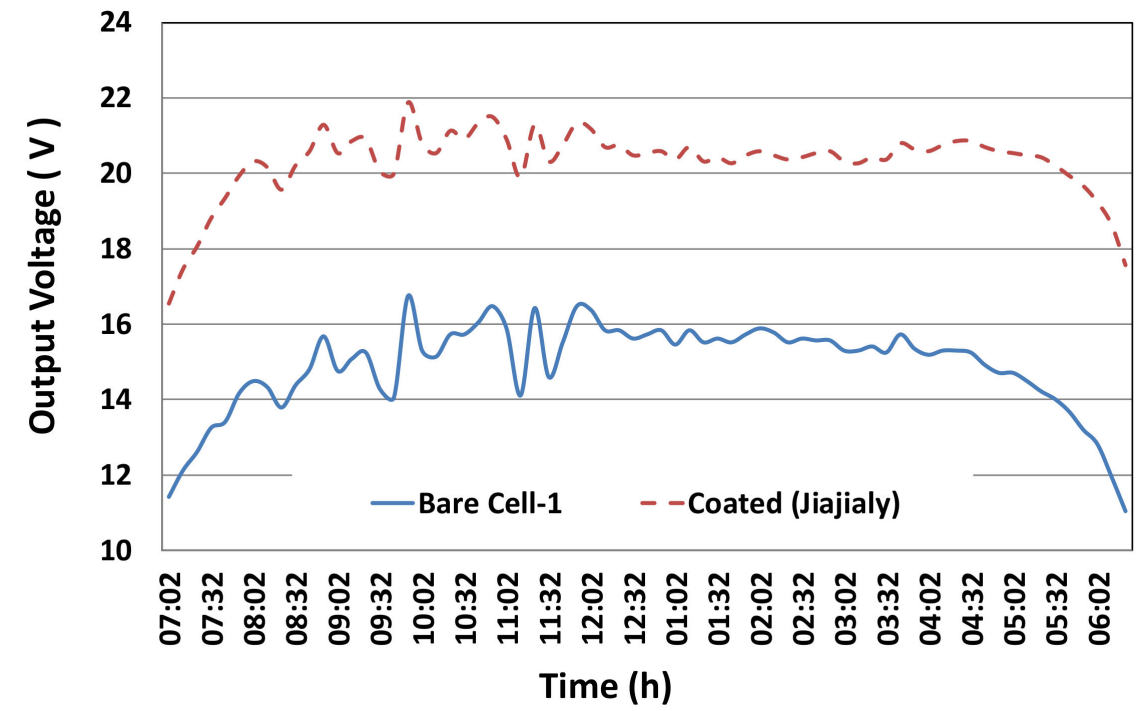

Figure 8. Voltage difference of PVs with and without Jiajialy nano energy saving and anti-UV solution, Amman-Jordan.

\subsection{Material GIE (Galsilk 7, Isopropanol, Ethanol, Water)}

Galsilk 7 is a hydrophilic highly charged cationic copolymer of diallyl dimethyl ammonium chloride and acrylamide, which was prepared for the experiment by mixing it with isopropanol, ethanol and water. Coating the cell glass gives a thin white layer as seen in Figure 9. During the measurement day, weather was moderate and it should be reported that dust was not removed easily by air blowing. 


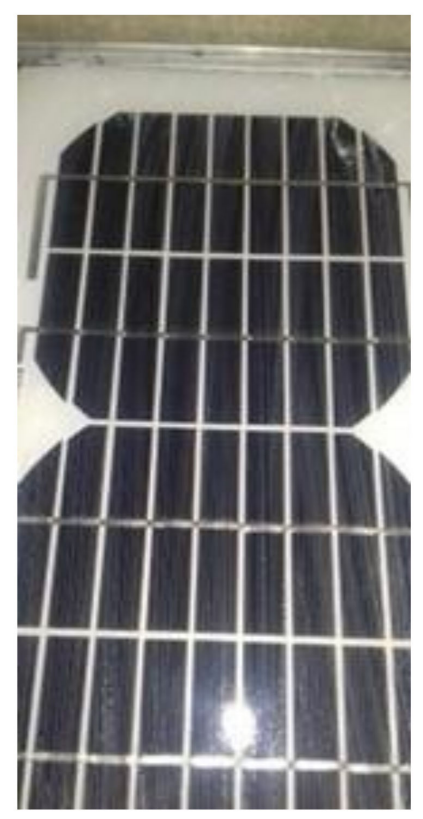

Figure 9. GIE (Galsilk 7, isopropanol, ethanol, water) solution.

Figure 10 shows that GIE coating material was able to decrease the cell temperature by a notable amount during the total measuring time period. This was due to a lower amount of ultraviolet sun rays (UV) penetrating through the coated glass. Consequently, there has been a noticed improvement in the output voltage for the coated surface over the uncoated surface as shown by Figure 11, keeping in mind the difference in measurement between the two cells as noted in Figure 2. As could be seen, GIE was able to reduce cell temperature and improve the output measured voltage. Therefore, GIE was selected for farther investigation by adding $\mathrm{TiO}_{2}$ nanoparticles to improve its easy-to-clean properties and performance.

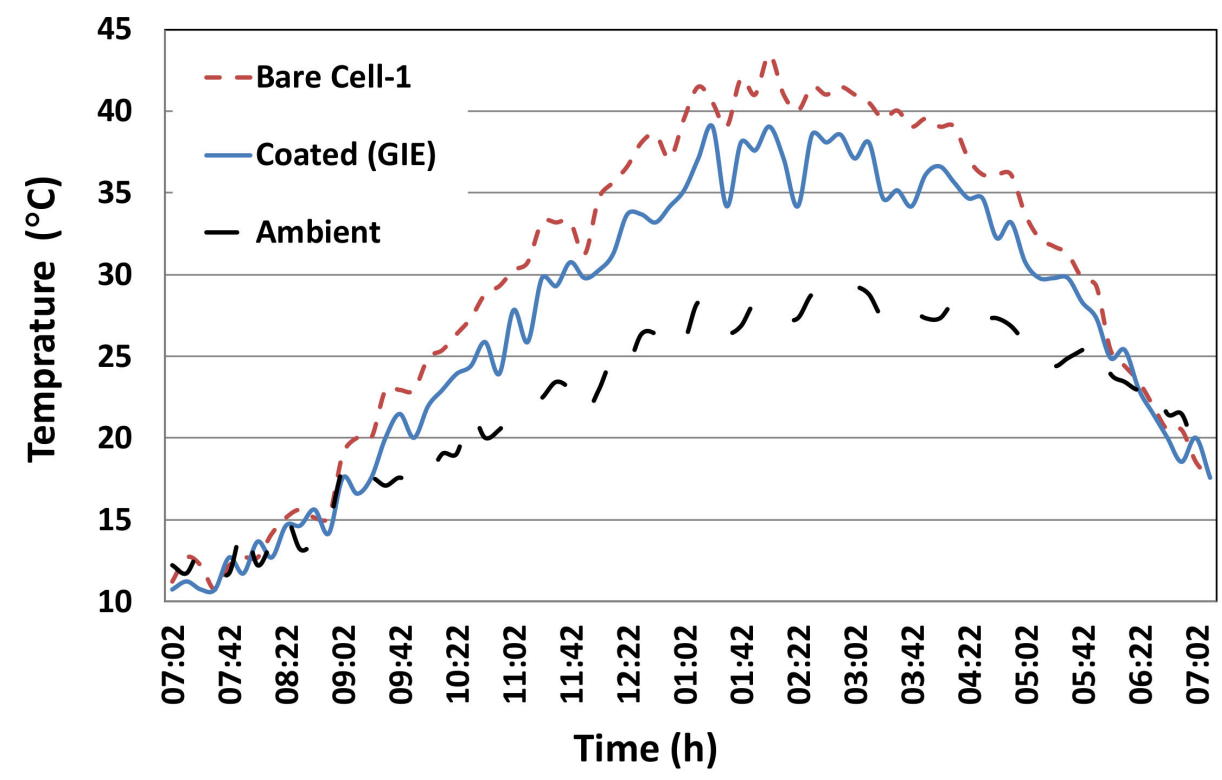

Figure 10. Temperature difference of PVs with and without GIE (Galsilk 7, isopropanol, ethanol, water), Amman-Jordan. 


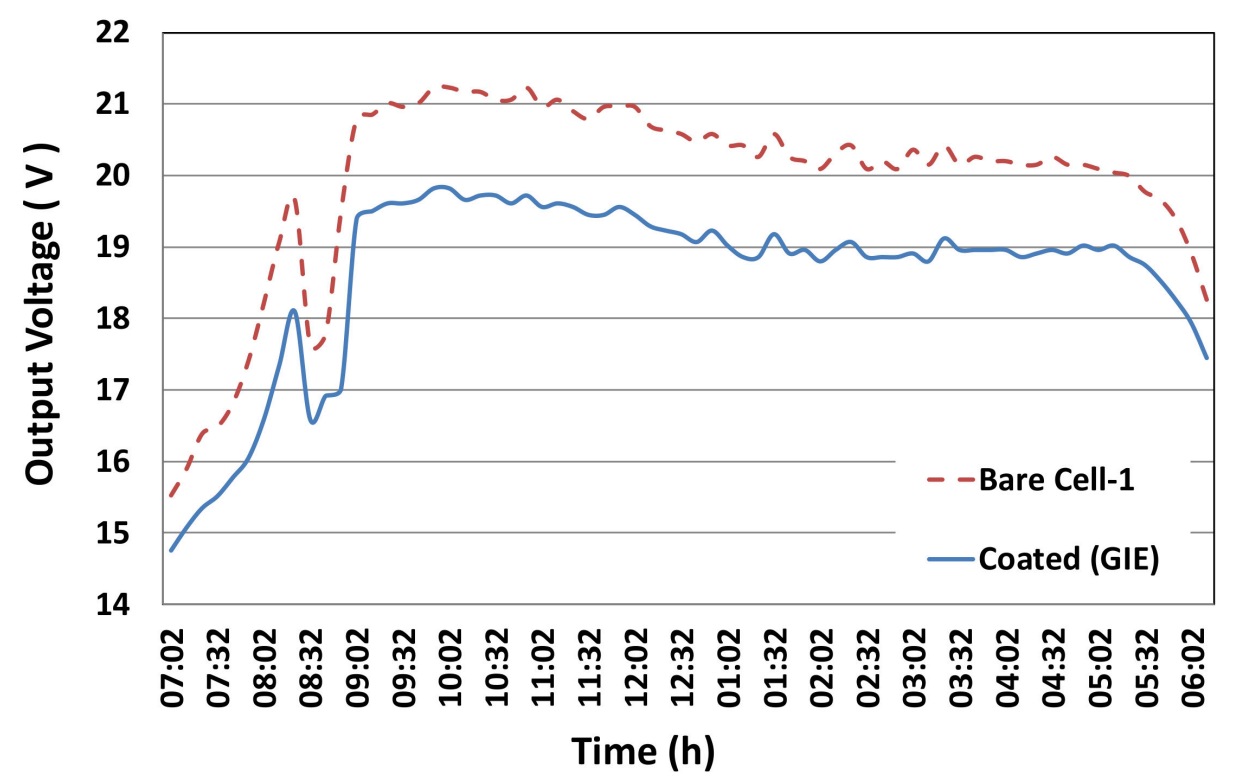

Figure 11. Voltage difference of PVs with and without GIE (Galsilk 7, isopropanol, ethanol, water), Amman-Jordan.

\subsection{TGIE ( $\mathrm{TiO}_{2}$, Galsilk 7, Isopropanol, Ethanol, Water)}

TGIE is a hydrophilic mixture from different components mainly $\mathrm{TiO}_{2}$ nanoparticles, isopropanol, ethanol, Galsilk 7 and water. It has been developed in house to improve the efficiency of cleaning materials. Figure 12 shows coated cell glass, which gives a thin white clear layer.

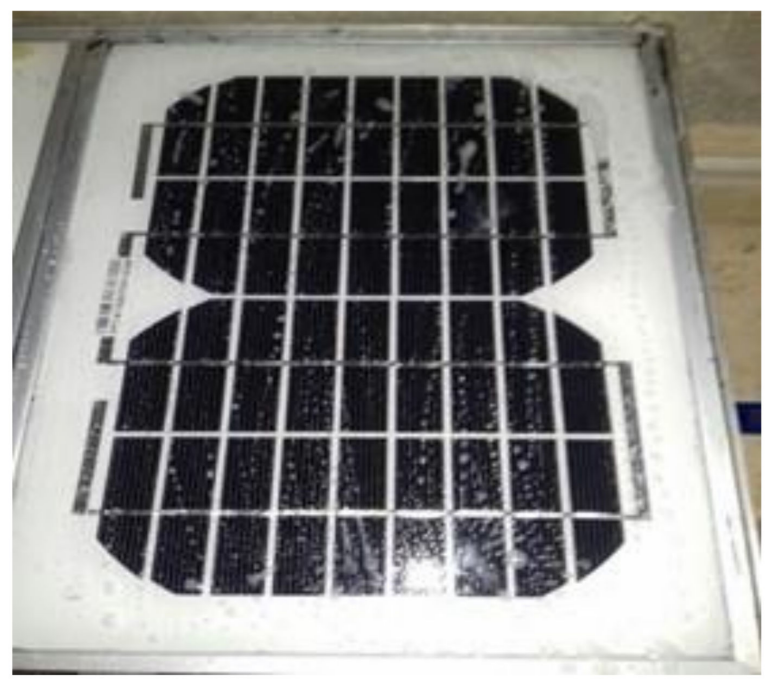

Figure 12. TGIE ( $\mathrm{Tio}_{2}$, Galsilk 7, isopropanol, ethanol, water) solution.

$\mathrm{TiO}_{2}$ nanoparticles are the most common hydrophilic material used in self-cleaning applications. $\mathrm{TiO}_{2}$ nanoparticles work in two steps: split of organic dirt via photocatalytic process in the presence of ultraviolet light and the diffusion of water to the whole surface instead of getting together due to the hydrophilicity of $\mathrm{TiO}_{2}$ to rinse the dust. $\mathrm{Also}, \mathrm{TiO}_{2}$ nanoparticles exhibit long-term stability and good chemical and mechanical properties with high thermal resistance and low costs [12,22].

Figure 13 shows a slight improvement of coated cells compared with bare ones, with max difference in temperature being found around midday when the temperature was high. The measured difference in output voltage was notable without big improvements 
from GIE materials as shown by Figure 14. The only noted improvement was that dust was removed easily by air blowing.

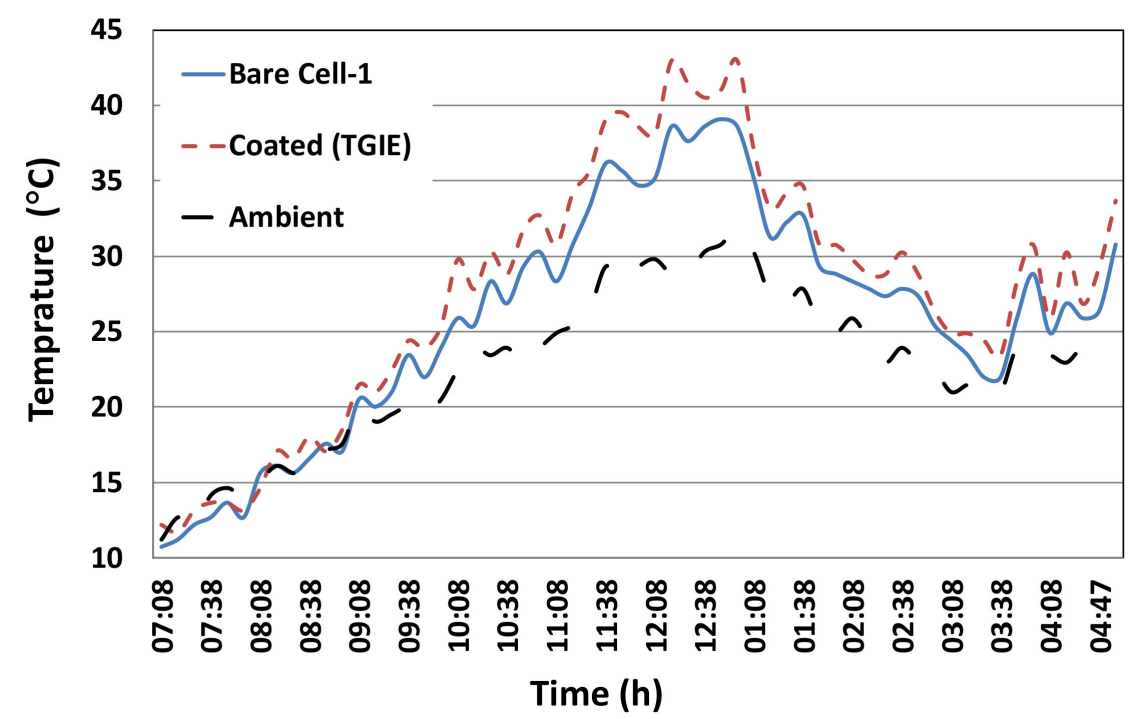

Figure 13. Temperature difference of PVs with and without TGIE (Tio ${ }_{2}$, Galsilk 7, isopropanol, ethanol, water) solution, Amman-Jordan.

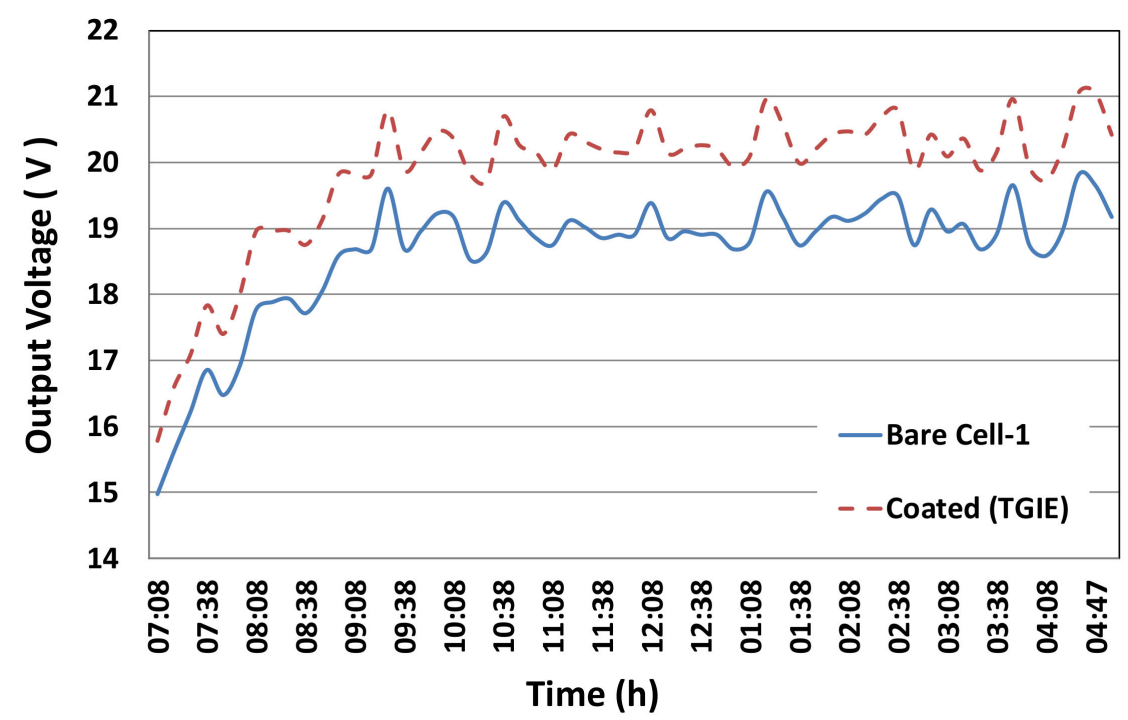

Figure 14. Voltage difference of PVs with and without TGIE ( $\mathrm{Tio}_{2}$, Galsilk 7, isopropanol, ethanol, water) solution, Amman-Jordan.

\subsection{Sodium Hexa Meta Phosphate}

Sodium hexa meta phosphate is hydrophilic. It was used to give the surface a negative sign and solubility in water. Coating the cell glass gives a thin layer as seen in Figure 15. It is worth mentioning that it was difficult to coat this material on glass. During the measurement day, the weather was hot and dust was not removed easily by air blowing from the top of the coated cell glass.

Figures 16 and 17 show that sodium hexametaphosphate solution coating material affected the coated cell in negative direction by increasing the cell temperature and decreasing the output voltage This is because sodium hexametaphosphate solution decreased the transparency of cell glass and reduced the amount of visible light that reached the silicon layer. The visible light is responsible for producing the energy without any effect on lowering the amount of ultraviolet sun rays that penetrate through the coated glass. 


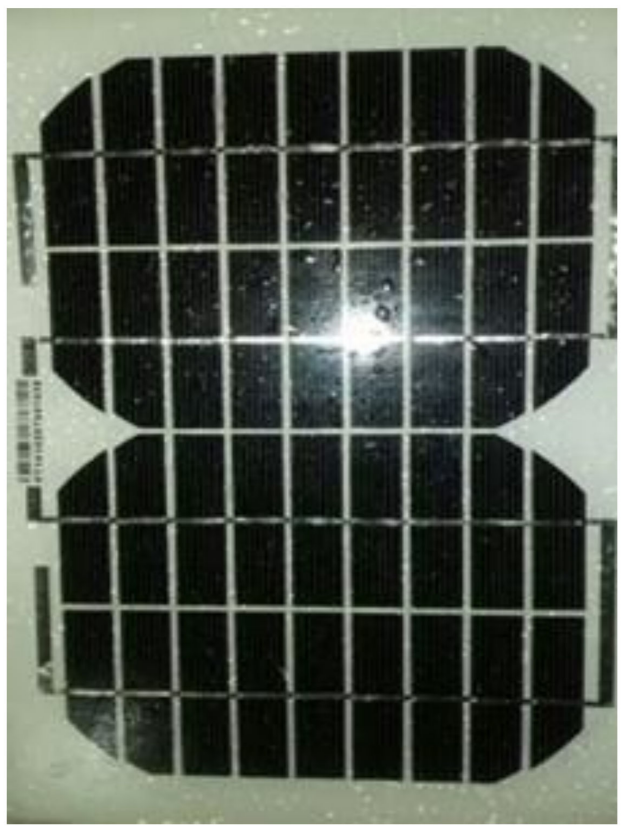

Figure 15. Sodium hexametaphosphate solution.

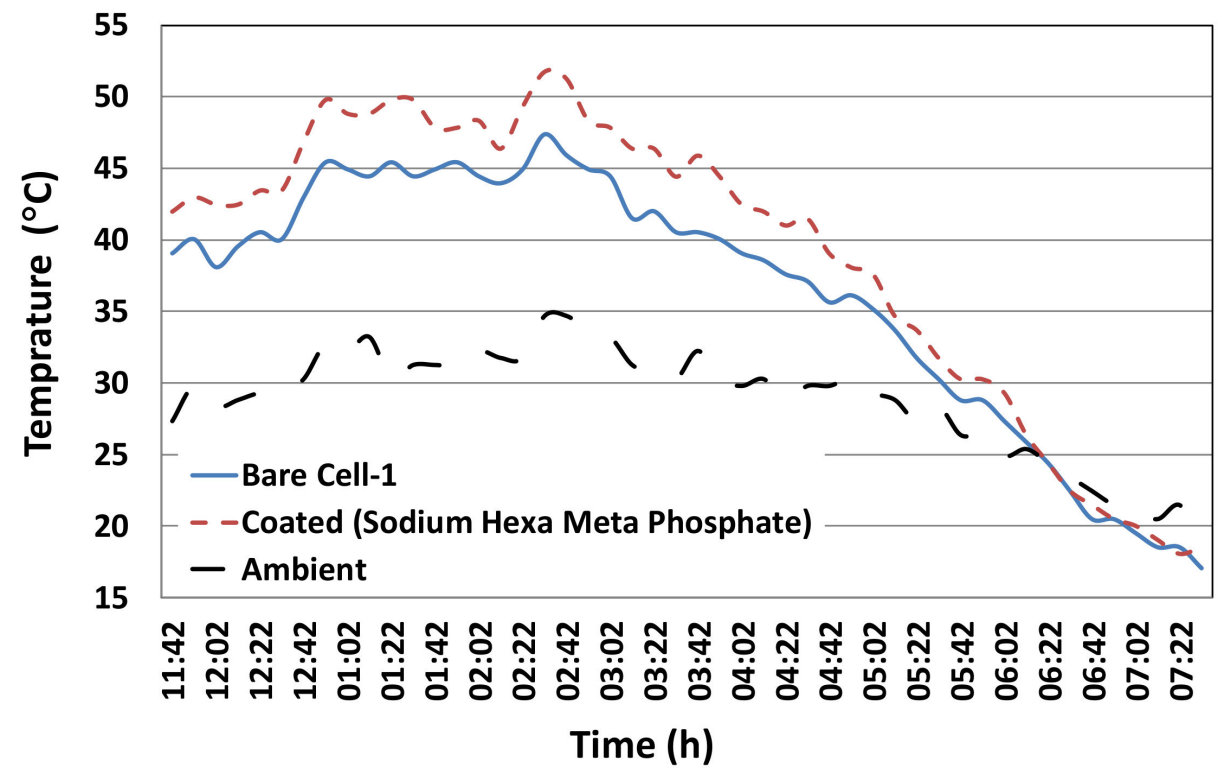

Figure 16. Temperature difference of PVs with and without sodium hexametaphosphate solution, Amman-Jordan. 


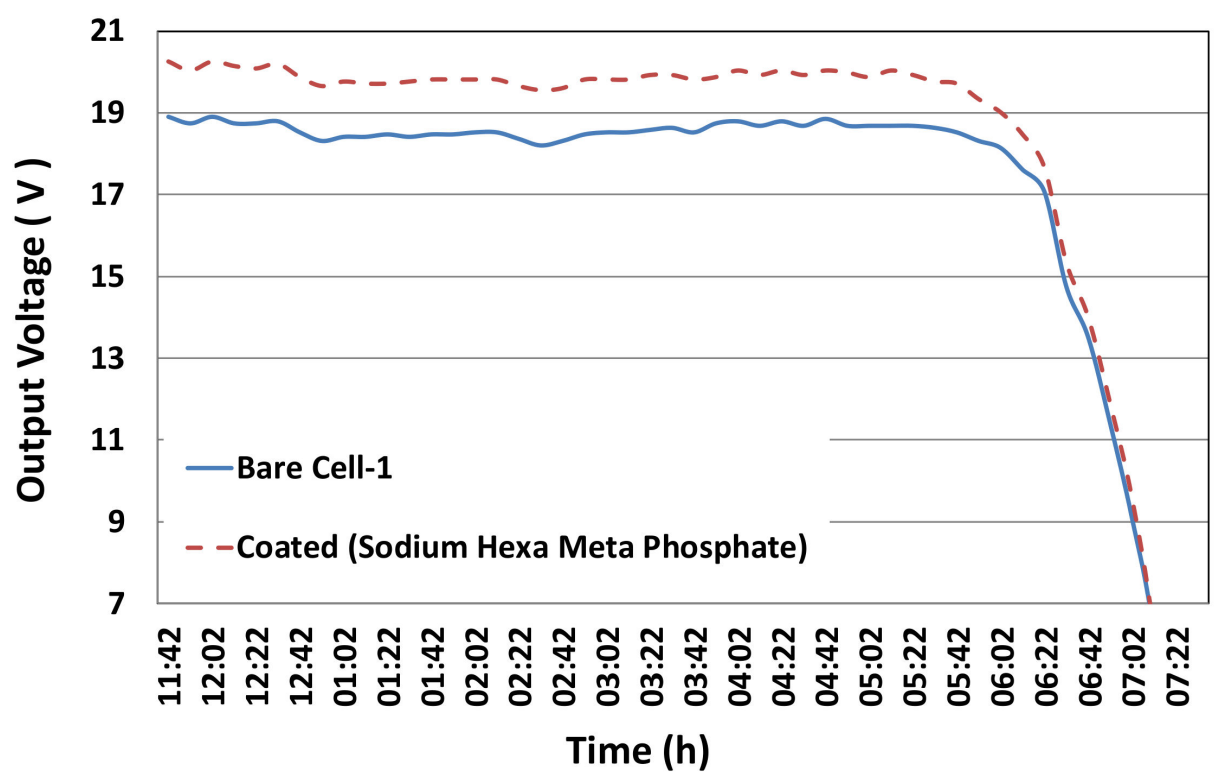

Figure 17. Voltage difference of PVs with and without sodium hexametaphosphate solution, Amman-Jordan.

\subsection{Nano Ultra Architectural Glass Stain Remover and Polish}

It is a superhydrophobic transparent stain remover and polish that efficiently removes most corrosion including nano cerium oxide $\left(\mathrm{CeO}_{2}\right)$, stubborn calcium, magnesium, iron, and silicate stains without mechanical buffing. Normally, it is used in glass cleaning since it imparts a protection to the glass surface that is hydrophilic, allowing water to create a sheeting action that washes away dirt and grime. Measurement day weather was hot and cloudy. Dust was removed easily by air blowing from the top of the coated cell glass with a reduced amount of dust on the panel surface.

Figure 18 shows the temperature variation for coated and bare cells. The temperature difference between bare cell and the coated cell at early morning and at midday showed that the NanoUltra material acts better at reducing the cell temperature by a slight value of around $1.5^{\circ} \mathrm{C}$. Consequently, there has been a noticed light improvement of the output voltage for the coated surface over the uncoated surface as shown by Figure 19. We should keep in mind the difference in measurement between the two cells as noted in Figure 2.

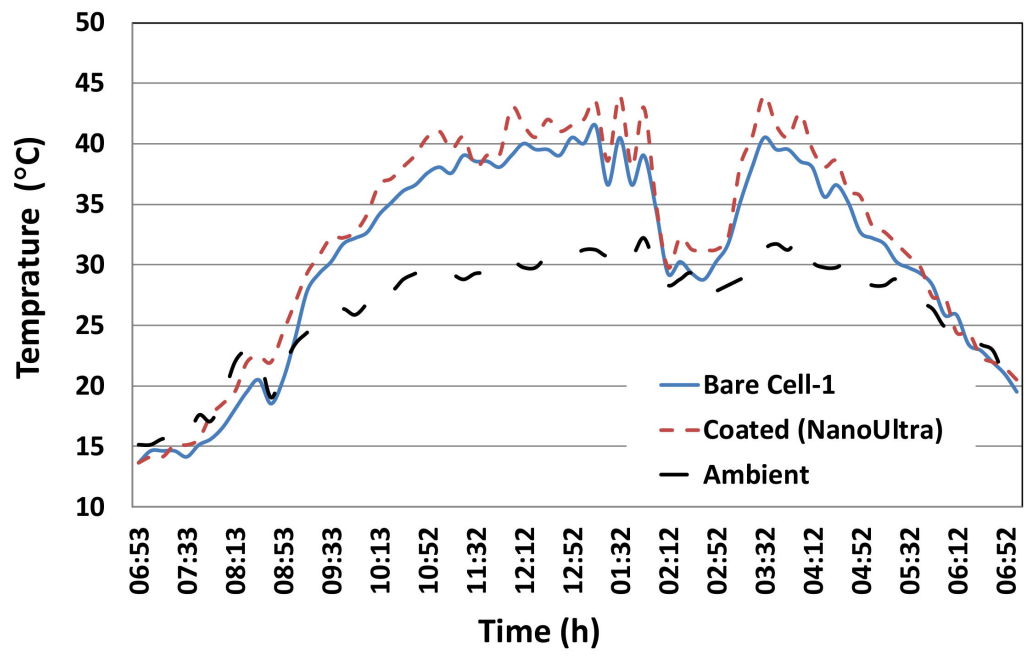

Figure 18. Temperature difference of PVs with and without Nano Ultra Architectural Glass Stain Remover and Polish Solution, Amman-Jordan. 


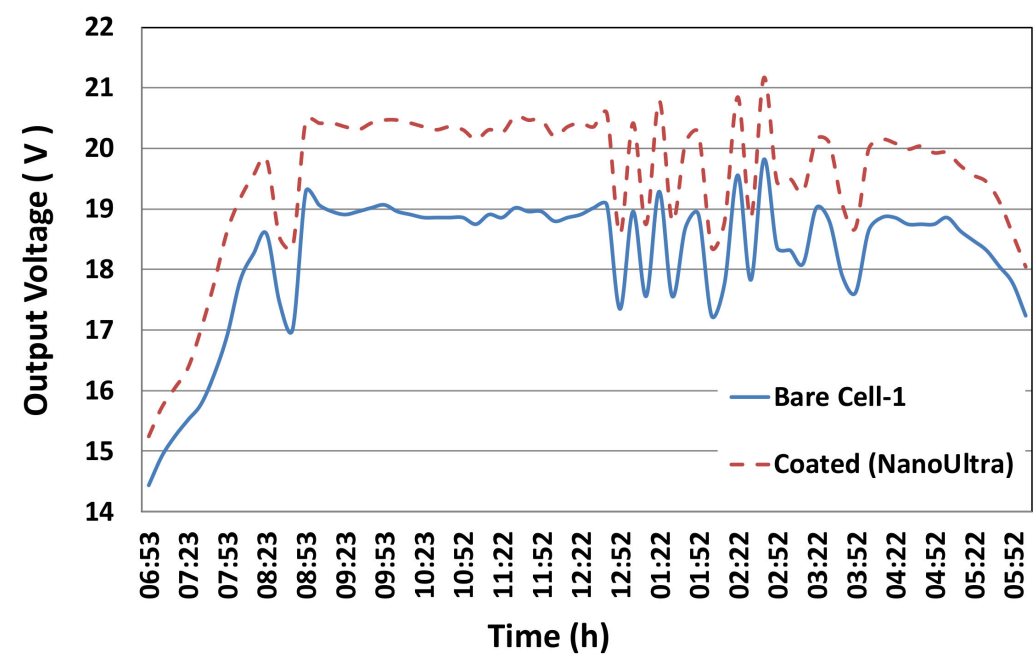

Figure 19. Voltage difference of PVs with and without Nano Ultra Architectural Glass Stain Remover and Polish Solution, Amman-Jordan.

\subsection{Comparison}

Figure 20 summarizes the influence of different coating materials on coated cell temperature. It is clear that all cells showed an effect on reducing the cell temperature in variable rates. The AJJL-CSS showed lower cell temperature but unfortunately with lower output voltage, while the GIE and TGIE showed similar results.

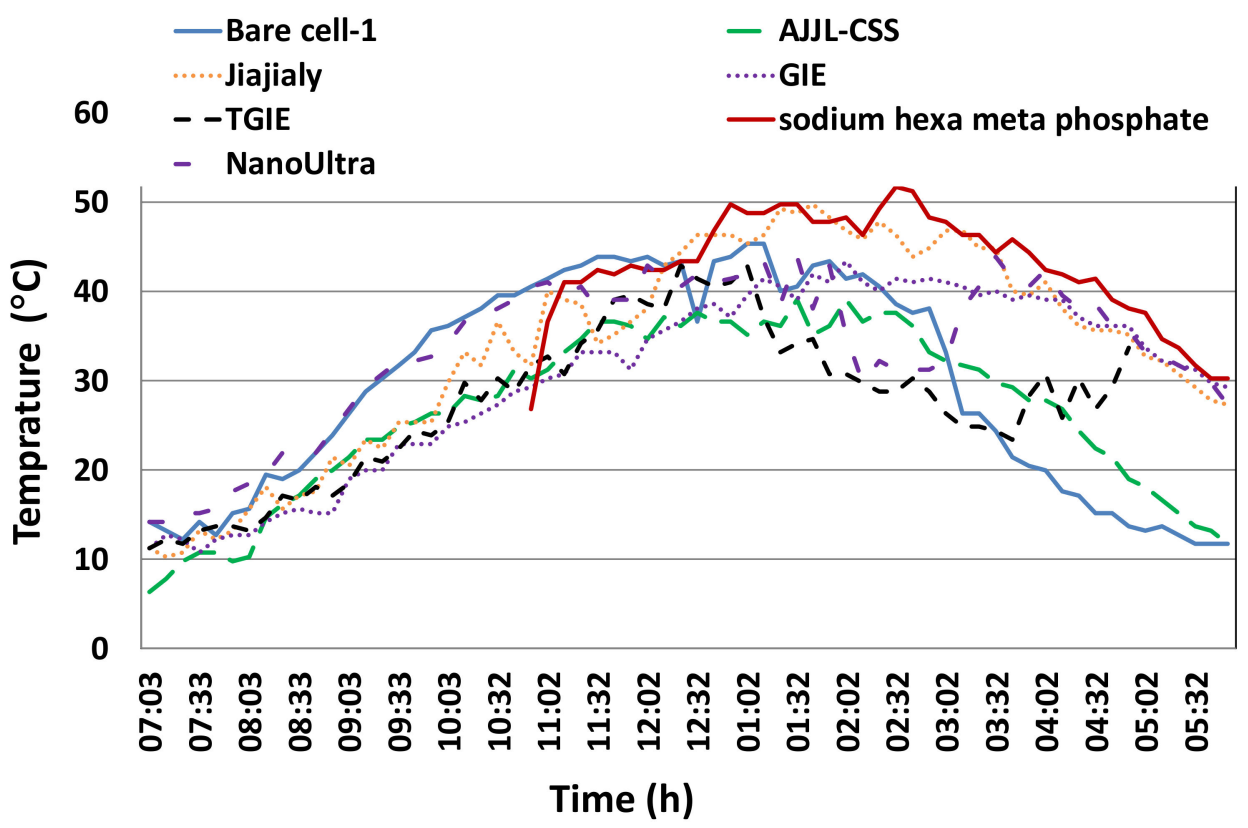

Figure 20. Measured temperature of coated PVs for all tested easy-to-clean coating materials, Amman-Jordan.

Figure 21 showed the output voltage difference between investigated PVs with and without coating for all tested easy-to-clean coating material to find the best coating material with improvement in the output voltage of the cell. It is clear that the coating material GIE showed the best voltage difference. Also, the TGIE showed similar results with the advantage of it being easy to blow the dust from the top of the cell, as has been discussed before. 


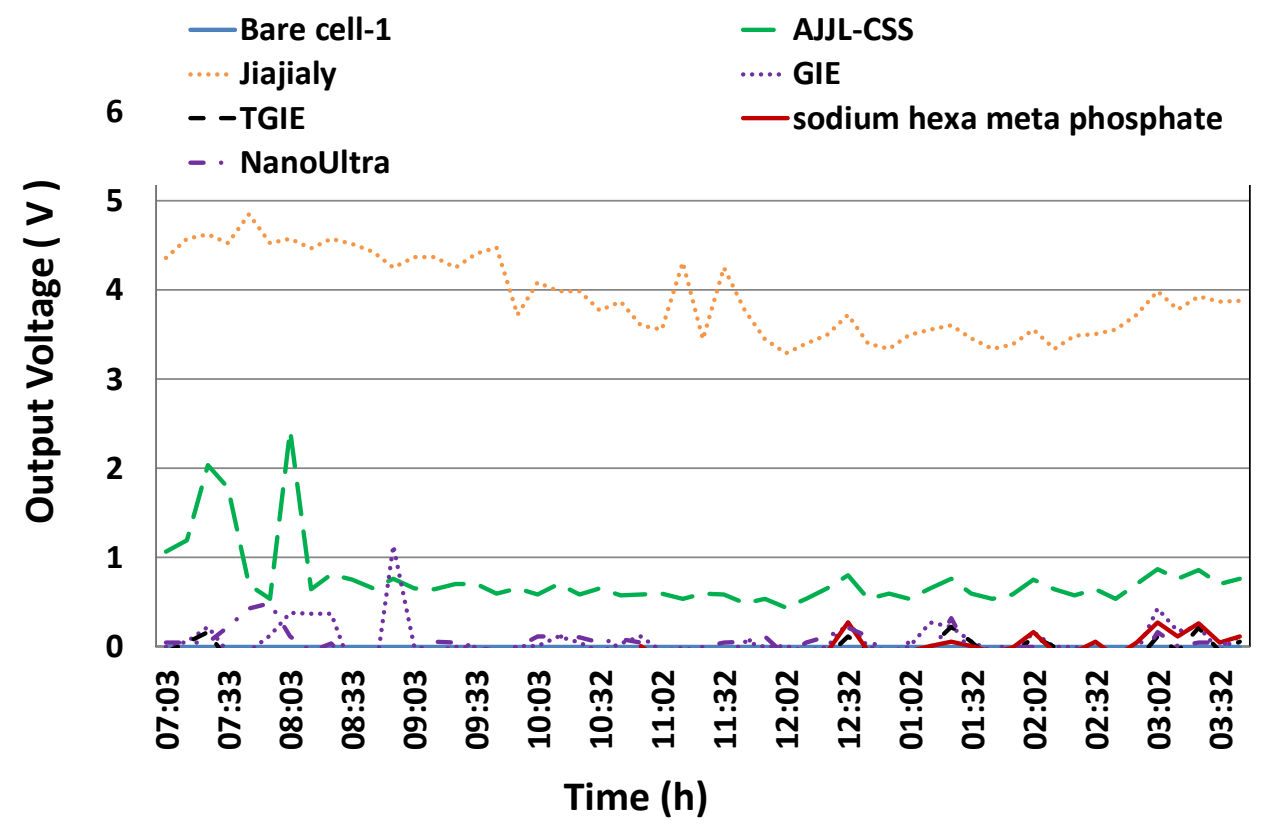

(a)

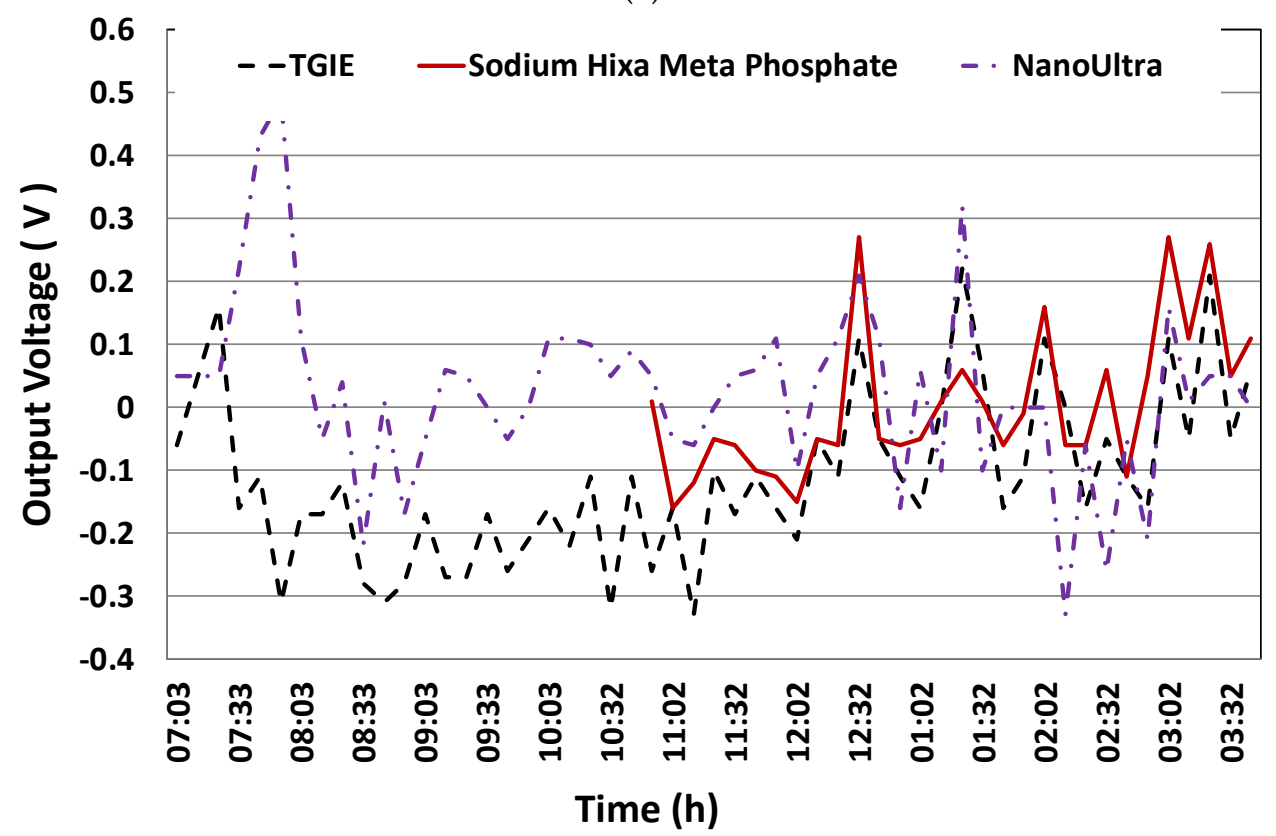

(b)

Figure 21. Voltage difference of PVs with and without coating for all tested easy-to-clean coating material $\left(\mathrm{V}_{2}-\mathrm{V}_{1}\right)$ : (a) all tested materials, (b) best performing materials.

\section{Conclusions}

The focus of the current study was on investigating the effects of different easy-to-clean materials on the performance of polycrystalline silicon panels experimentally. This was achieved by coating the cell surface with different types of easy-to-clean materials founded in the local market and one in-house developed material. The main cleaning materials and techniques that were compared in this study were: Crystal glass coating type AJJL-CSS jiajialy nano energy saving and anti UV solution, GIE, TGIE, sodium hexa-metaphosphate and Nano Ultra.

The full-scale measurements of cell temperatures and output voltage of the investigated cell, both bare cells and coated cells, showed that all applied coating materials 
were able to reduce the cell temperature with different scales. The Jiajialy Nano energy saving and anti UV solution showed the best cooling effect that resulted in lowest cell temperature. The GIE and TGIE coating materials showed similar trends in reducing cell temperatures. Furthermore, the output voltage of the investigated cells coated with GIE and TGIE materials showed the best results with high voltage outputs.

The GIE and TGIE coating materials showed optimal results with a slight advantage for TGIE coating material. Utilizing the TGIE coating materials made it easier to blow the dust from the top of the cell surface, which resulted in a lower accumulating amount of dust. It is worth mentioning that all cleaning techniques were simultaneously used to increase cleaning efficiency by reducing dust accumulation, by reversing ultraviolet radiation and by reducing cell temperature. This led to improving the electrical efficiency of the photovoltaic cells.

The current investigation is part of an ongoing project that is concerned with finding the optimum effect of GIE and TGIE on solar cell temperature by using different concentrations of $\mathrm{TiO}_{2}$ nanoparticles in the coated material mixture. Moreover, effects of using a spin coating machine would yields a thinner coating layer which could result in more accurate results. This is to be examined in future work.

Author Contributions: Conceptualization, K.A. and R.A.-W.; methodology, K.A.; software, K.A.; validation, K.A. and R.A.-W.; formal analysis, K.A. and R.A.-W.; writing-original draft preparation, K.A.; writing-review and editing, R.A.-W.; All authors have read and agreed to the published version of the manuscript.

Funding: This research received no external funding.

Institutional Review Board Statement: Not Applicable.

Informed Consent Statement: Not Applicable.

Data Availability Statement: Data is contained within the article.

Acknowledgments: Authors would like to acknowledge the assistance provide by Assim Alqassem in field measurements. Support provided by the Deanship of Scientific Research of both Al Balqa Applied University (BAU) and the German Jordanian University (GJU), Jordan are gratefully acknowledged.

Conflicts of Interest: The authors declare no conflict of interest.

\section{References}

1. Mani, M.; Pillai, R. Impact of dust on solar photovoltaic (PV) performance: Research status, challenges and recommendations. Renew. Sustain. Energy Rev. 2010, 14, 3124-3131. [CrossRef]

2. Erdenedavaa, P.; Rosato, A.; Adiyabat, A.; Akisawa, A.; Sibilio, S.; Ciervo, A. Model Analysis of Solar Thermal System with the Effect of Dust Deposition on the Collectors. Energies 2018, 11, 1795. [CrossRef]

3. Tanesab, J.; Parlevliet, D.; Whale, J.; Urmee, T. Seasonal effect of dust on the degradation of PV modules performance deployed in different climate areas. Renew. Energy 2017, 111, 105-115. [CrossRef]

4. Al-Housani, M.; Bicer, Y.; Koç, M. Assessment of Various Dry Photovoltaic Cleaning Techniques and Frequencies on the Power Output of CdTe-Type Modules in Dusty Environments. Sustainability 2019, 11, 2850.

5. Denholm, P.; Drury, E.; Margolis, R.; Mehos, M. Solar energy: The largest energy resource. In Generating Electricity in a Carbon-Constrained World; Sioshansi, F.P., Ed.; Academic Press: Cambridge, MA, USA, 2010; pp. 271-302.

6. Sarver, T.; Al-Qaraghuli, A.; Kazmerski, L.L. A comprehensive review of the impact of dust on the use of solar energy: History, investigations, results, literature, and mitigation approaches. Renew. Sustain. Energy Rev. 2013, 22, 698-733. [CrossRef]

7. Maghami, M.R.; Hizam, H.; Gomes, C.; Radzi, M.A.; Rezadad, M.I.; Hajighorbani, S. Power loss due to soiling on solar panel: A review. Renew. Sustain. Energy Rev. 2016, 59, 1307-1316. [CrossRef]

8. Lee, S.-H.; Han, K.-S.; Shin, J.-H.; Hwang, S.-Y.; Lee, H. Fabrication of highly transparent self-cleaning protection films for photovoltaic systems. Prog. Photovolt. Res. Appl. 2012, 21, 1056-1062. [CrossRef]

9. Yilbas, B.S. A new dimension in self-cleaning of solar energy harvesting devices. Int. J. Energy Res. 2017, 41, 1944-1947. [CrossRef]

10. Syafiq, A.; Pandey, A.; Adzman, N.; Rahim, N.A. Advances in approaches and methods for self-cleaning of solar photovoltaic panels. Sol. Energy 2018, 162, 597-619. [CrossRef]

11. Liang, Z.; Zhou, Z.; Zhao, L.; Dong, B. Fabrication of transparent, durable and self-cleaning superhydrophobic coatings for solar cells. New J. Chem. 2020, 44, 14481-14489. 
12. Isaifan, R.J.; Samara, A.; Suwaileh, W.; Johnson, D.; Yiming, W.; Abdallah, A.A.; Aïssa, B. Improved Self-cleaning Properties of an Efficient and Easy to Scale up TiO2 Thin Films Prepared by Adsorptive Self-Assembly. Sci. Rep. 2017, 7, 9466. [CrossRef]

13. He, G.; Zhou, C.; Li, Z. Review of Self-Cleaning Method for Solar Cell Array. Procedia Eng. 2011, 16, 640-645. [CrossRef]

14. Piliougine, M.; Cañete, C.; Moreno, R.; Carretero, J.; Hirose, J.; Ogawa, S.; Sidrach-De-Cardona, M. Comparative analysis of energy produced by photovoltaic modules with anti-soiling coated surface in arid climates. Appl. Energy 2013, 112, 626-634. [CrossRef]

15. Kim, Y.D.; Shin, J.-H.; Cho, J.-Y.; Choi, H.-J.; Lee, H. Nanosized patterned protective glass exhibiting high transmittance and self-cleaning effects for photovoltaic systems. Phys. Status Solidi 2014, 211, 1822-1827. [CrossRef]

16. Pedersen, H.; Strauss, J.; Selj, J. Effect of Soiling on Photovoltaic Modules in Norway. Energy Procedia 2016, 92, 585-589.

17. Oh, W.; Kang, B.; Choi, S.; Bae, S.; Jeong, S.; Kim, S.M.; Lee, H.-S.; Kim, D.; Hwang, H.; Chan, S.-I. Evaluation of Anti-Soiling and Anti-Reflection Coating for Photovoltaic Modules. J. Nanosci. Nanotechnol. 2016, 16, 10689-10692. [CrossRef]

18. Arabatzis, I.; Todorova, N.; Fasaki, I.; Tsesmeli, C.; Peppas, A.; Li, W.X.; Zhao, Z. Photocatalytic, self-cleaning, antireflective coating for photovoltaic panels: Characterization and monitoring in real conditions. Sol. Energy 2018, 159, 251-259. [CrossRef]

19. Dash, P.; Gupta, N.C. Effect of Temperature on Power Output from Different Commercially available Photovoltaic Modules. Int. J. Eng. Res. Appl. 2015, 5, 148-151. [CrossRef]

20. Bazzari, H.H.; Abushgair, K.N.; Hamdan, M.A.; Alkhaldi, H.S. Cooling solar cells using ZnO nanoparticles as a down-shifter. Therm. Sci. 2020, 24, 809-814. [CrossRef]

21. Bendary, A.; Abdelaziz, A.; Ismail, M.; Mahmoud, K.; Lehtonen, M.; Darwish, M. Proposed ANFIS Based Approach for Fault Tracking, Detection, Clearing and Rearrangement for Photovoltaic System. Sensors 2021, 21, 2269. [CrossRef]

22. Li, Z.; Dong, Y.; Li, B.; Wang, P.; Chen, Z.; Bian, L. Creation of self-cleaning polyester fabric with TiO2 nanoparticles via a simple exhaustion process: Conditions optimization and stain decomposition pathway. Mater. Des. 2018, 140, 366-375. [CrossRef] 